\title{
PENGARUH PENDIDIKAN KARAKTER TERHADAP PERILAKU SISWA MI
}

\author{
Firda Halawati \\ Dicky Fauzi Firdaus \\ fbayasut90@yahoo.com \\ df.firdaus.20@gmail.com \\ Universitas Islam Al-Ihya Kuningan
}

\begin{abstract}
Abstrak: Penelitian ini bertujuan untuk mengetahui (1) Bagaimana pendidikan karakter siswa MI? (2) Bagaimana perilaku siswa MI? (3) Apakah ada pengaruh pendidikan karakter terhadap perilaku siswa MI. Penelitian ini menggunakan penelitian kuantitatif dengan jenis penelitian survey. Teknik pengambilan sampel menggunakkan simple random sampling diperoleh sampel 88 siswa. Teknik pengumpulan data dengan menggunakan instrument angket, observasi dan dokumentasi. Hasil penelitian ini menunjukkan bahwa (1) Pendidikan karakter siswa MI tergolong sangat tinggi dengan persentasi 88,64\%, (2) Perilaku siswa MI menunjukan kategori sangat baik sebesar 77,27\%, (3) Terdapat pengaruh positif antara pendidikan karakter terhadap perilaku siswa MI. Dimana apabila pendidikan karakter siswa meningkat 1\% maka akan diikuti pula peningkatan perilaku siswa sebesar 0,471 . Pada uji f diperoleh $\mathrm{f}_{\text {hitung }}$ sebesar 4,483 dan nilai ftabel taraf sig $5 \%$ sebesar 3,39. Berdasarkan hasil analisis regresi diperoleh nilai $r$ sebesar 0,446 dan $\mathrm{r}^{2}$ sebesar 0,526 . Hal ini berarti bahwa pengaruh pendidikan karakter terhadap perilaku siswa sebesar $52,6 \%$, sedangkan sisanya dipengaruhi oleh faktor lain diluar dari variabel dalam penelitian ini.
\end{abstract}

Kata Kunci: Pendidikan Karakter, Perilaku Siswa .

Abstract: This study aims to determine (1) How is the character education of MI students? (2) What is the behavior of MI students? (3) Is there any influence of character education on MI student behavior. This research uses quantitative research with survey research type. The sampling technique using simple random sampling obtained a sample of 88 students. Data collection techniques using questionnaire instruments, observation and documentation. The results of this study indicate that (1) MI student character education is classified as very high with a percentage of $88.64 \%$, (2) MI student behavior shows a very good category of $77.27 \%$, (3) There is a positive influence between character education on student behavior MI Where if student character education increases by $1 \%$, it will also be followed by an increase in student behavior by 0.471. In the $f$ test, the fcount of 4.483 was obtained and the significance level of the significance level of 5\% was 3.39. Based on the results of regression analysis, the value of $r$ is 0.446 and $r 2$ is 0.526 . This means that the influence of character education on student behavior by $52.6 \%$, while the rest is influenced by other factors outside the variables in this study.

Keywords: Character Education, Student Behavior

\section{PENDAHULUAN}

Pendidikan adalah salah satu harapan besar bagi negeri ini agar bisa bangkit dari keterpurukan dalam semua aspek kehidupan. Pada zaman modern ini bangsa Indonesia mengalami krisis moral dan perilaku sehingga membutuhkan upaya atau program nyata untuk menyelesaikan permasalahan ini, salah satunya dengan menanamkan pendidikan 
karakter. Dengan demikian lembaga sekolah menanamkan pendidikan karakter untuk membentuk perilaku dan kepribadian siswa. Sekolah dan madrasah termasuk pendidikan yang formal. Sebagai lembaga pendidikan formal, sekolah mempunyai kewajiban untuk membentuk perilaku siswa yang baik. Maka dari itu, dituangkanlah pendidikan karakter di sekolah.

Pendidikan karakter adalah suatu sistem penanaman nilai-nilai karakter kepada warga sekolah yang meliputi komponen pengetahuan, kesadaran atau kemauan, dan tindakan untuk melaksanakan nilai-nilai tersebut, baik terhadap Tuhan Yang Maha Esa (YME), diri sendiri, sesama, lingkungan, maupun kebangsaan sehingga menjadi manusia insan kamil. Sebagai upaya untuk meningkatkan kesesuaian dan mutu pendidikan karakter, Kementerian Pendidikan Nasional mengembangkan grand design (rancangan besar) tentang pendidikan karakter untuk setiap jalur, jenjang, dan jenis satuan pendidikan.

Bagaimanapun juga pendidikan karakter sangat penting bagi peserta didik. Melalui pendidikan karakter inilah, para peserta didik lebih berpeluang memiliki perilaku yang bertanggung jawab sebagai generasi penerus bangsa. Selain itu, karakter merupakan aspek yang penting untuk kesuksesan manusia di masa depan. Pendidikan karakter memiliki fungsi yaitu untuk mengembangkan potensi dasar agar berhati baik, berpikiran baik, dan berperilaku baik, untuk memperkuat dan membangun perilaku bangsa yang multikultur, dan untuk meningkatkan peradaban bangsa yang kompetitif dalam pergaulan dunia. Pada dunia pendidikan banyak membicarakan mengenai pendidikan karakter. Dengan fakta yang menunjukkan bahwa karakter bangsa pada zaman globalisasi ini merosot dengan sangat tajam. Dengan merosotnya karakter bangsa maka tidak jauh kemungkinan karakter peserta didik juga akan merosot, karena sedikitnya dampak negatif globalisasi akan menyerang kepada anak-anak, sehingga akan mempengaruhi pada hasil belajar di sekolah terutama pada mata pelajaran PKN. Materi pembelajaran yang berkaitan dengan norma atau nilai-nilai pada setiap mata pelajaran perlu dikembangkan, dikaitkan dengan konteks kehidupan sehari-hari. Moralitas menjadi longgar adalah salah satu dampak negatif globalisasi. Sesuatu yang dahulu dianggap tabu, sekarang menjadi biasa-biasa saja. Cara berpakaian, berinteraksi dengan lawan jenis, sikap siswa kepada guru tidak sopan, melawan dan membantah perintah guru dan lain sebagainya. Akhirnya, karakter anak bangsa berubah menjadi rapuh, terjerumus dalam budaya asing yang melenakan, dan tidak memikirkan akibat yang ditimbulkan. Kondisi yang demikian akan menjadikan tantangan yang semakin berat bagi dunia pendidikan, bagaimana cara membangun perilaku siswa yang sesuai dengan norma. Dampak negatif globalisasi telah mengakibatkan nilai-nilai moral, semangat patriotisme dan karakter dari individu dan masyarakat bangsa dan negara kita semakin memudar. Hal ini membuat lembaga pendidikan berjalan stagnan (keadaan yang terhenti), bahkan terkesan mundur. Prinsipprinsip moral, budaya bangsa, dan perjuangan dari karakteristik mereka karena terkikis oleh globalisasi. Inilah yang menyebabkan dekadensi moral serta hilangnya kreativitas dan produktivitas bangsa. Hal ini lah yang melatar belakangi munculnya pendidikan berkarakter. Pendidikan sendiri dianggap sebagai suatu media yang paling jitu dalam mengembangkan potensi anak didik baik berupa keterampilan maupun wawasan. Oleh karena itu, pendidikan secara terus menerus dibangun dan dikembangkan agar dari proses pelaksanaannya menghasilkan generasi yang diharapkan.

Fakta perilaku siswa yang menyimpang akibat tidak ditanamkannya pendidikan karakter di sekolah. Peneliti Komnas Perlindungan Anak (KPAI), yakni pelaku kriminal 
dari kalangan siswa mengalami peningkatan. Berdasarkan data yang ada, terhitung sejak bulan Januari hingga Oktober 2009 meningkat 35\% dibanding tahun sebelumnya. Pelaku rata-rata umur 13 sampai 17 tahun dan yang dilakukannya itu tawuran antar sekolah. Berdasarkan hasil pengamatan terhadap pendidikan karakter yang terdapat MI Sindangjawa Kecamatan Kadugede Kabupaten Kuningan. Siswa MI Sindangjawa tidak sedikit yang masih berperilaku kurang baik, contohnya masih ada siswa berpakaian tidak sesuai dengan aturan, kurang menghormati temannya, tidak jarang siswa yang berkelahi, siswa yang tidak hormat kepada gurunya dan lain sebagainya. Mereka belum mencerminkan sebagai siswa yang berperilaku baik, kedisiplinan yang lemah, sehingga minat belajar yang hampir hilang, integrasi moral yang sering menyeleweng. Hal itu disebabkan karena pendidikan karakter di madrasah ini kurang di perhatikan. Upaya untuk membangun perilaku siswa di MI Sindangjawa masih kurang baik, sehingga masih banyak perilaku siswa yang tidak sesuai dengan norma. Selain itu orangtua mempunyai harapan besar dan sangat bergantung kepada pihak lembaga.

\section{LANDASAN TEORI}

\section{Konsep Pendidikan}

Menurut Danim (2011:2) istilah pendidikan sering disebut dengan sekolah, guru mengajar di kelas, atau satuan pendidikan formal. Selain itu, pendidikan adalah aktivitas semua potensi dasar manusia melalui interaksi antara manusia dewasa dengan yang belum dewasa. Sedangkan menurut Brubacher (Ahmadi dan Uhbiyati, 2007:7) mendefinisikan pendidikan sebagai suatu proses pengembangan potensi dasar manusia yang berkaitan dengan moral, intelektual dan jasmaninya untuk mencapai tujuan hidup dalam kerangka sistem sosial. Menurut Noor Syam (Oemar, 2003:10) mendefinisikan pendidikan sebagai aktivitas dan usaha manusia untuk meningkatkan kepribadiannya dengan jalan membina potensi-potensi pribadinya yaitu rohani (rasa, cipta, dan budi nurani) dan jasmani (panca indra serta keterampilan-keterampilan). Berdasarkan pendapat para ahli yang sudah dijelaskan diatas, maka peneliti dapat menyimpulkan bahwa pendidikan adalah suatu proses pengembangan potensi dasar manusia yang dilakukan secara sadar untuk mengubah tingkah laku manusia dengan melalui interaksi antara manusia sehingga mempunyai kemampuan untuk bertanggung jawab terhadap segala sesuatu.

\section{Konsep Karakter}

Karakter berasal dari kata bahasa latin yang berarti "dipahat". Secara harfiah, karakter artinya kualitas mental atau moral (Hidayatullah, 2009:1). Menurut Soedarsono (2009: 32) karakter adalah suatu nilai yang terpatri dalam diri kita melalui pendidikan, pengalaman, percobaan, pengorbanan dan pengaruh lingkung, di padukan dengan nilai nilai dalam diri manusia menjadi semacam nilai intrinsik yang wujud dalam sistem daya juang melandasi pemikiran, sikap dan prilaku. Menurut Hanna Djumhana Basman (Majid, 2012: 12) karakter merupakan aktualisasi diri dalam dan internalisasi nilai-nilai moral dari luar menjadi bagian kepribadiannya. Menurut Asmani (2012:19) Karakter yang kuat merupakan prasyarat untuk menjadi seorang pemenang dalam medan kompetisi kuat seperti saat ini dan yang akan datang. Dari beberapa pengertian diatas, dapat disimpulkan bahwa karakter adalah suatu sikap yang dimiliki seseorang yang menjadi 
suatu ciri khas orang tersebut yang biasanya terbentuk dengan sendirinya atau di pengaruhi oleh lingkungan di sekitar atau orang orang di sekitarnya.

\section{Konsep Pendidikan Karakter}

Cara untuk dapat memperbaiki perilaku pada diri siswa, diperlukan adanya pendidikan karakter di sekolah, yang diharapkan dengan adanya pendidikan karakter di sekolah, perilaku siswa akan lebih baik dan lebih sesuai dengan norma. Dengan dua pemahaman dasar tentang pendidikan dan karakter. Menurut Koesoema (2007:3) mencoba membuat sintesis tentang pendidikan karakter, yaitu karakter lebih bersifat subjektif, sebab berkaitan dengan struktur antropologis manusia dan tindakannya dalam memaknai kebebasannya sehingga ia mengukuhkan keunikannya berhadapan dengan orang lain. Menurut Aqib (2011:14) pendidikan karakter merupakan sebuah upaya untuk membentuk kepribadian yang kuat bagi siswa untuk mempersiapkan diri dalam era globalisasi. Pendidikan karakter bisa dilakukan 50\% melalui keluarga dan 50\% melalui sekolah. Kedua lembaga ini berperan sama penting dalam pengajaran nilai-nilai yang membentuk karakter siswa. Memberikan pendididkan karakter melalui nilai-nilai agama sehingga anak mempunyai pegangan yang kuat dan menjadi penyaring dari pengaruh media seperti televisi, internet, dan lingkungan pergaulan siswa. Menurut Sujak (2011:3) pendidikan karakter adalah suatu sistem penanaman nilai-nilai karakter kepada warga sekolah yang meliputi komponen pengetahuan, kesadaran atau kemauan, dan tindakan untuk melaksanakan nilai-nilai tersebut. Pendidikan karakter dapat dimaknai sebagai "the deliberate use of all dimenstions of school life to foster optimal character development". Lebih lanjut di jelaskan bahwa pendidikan karakter adalah segala sesuatu yang dilakukan guru, yang mampu mempengaruhi karakter peserta didik. Menurut beberapa pengertian para ahli, peneliti dapat menyimpulkan bahwa pendidikan karakter merupakan keseluruhan dinamika rasional antar pribadi dengan berbagai macam dimensi, baik dari dalam maupun dari luar dirinya. Agar pribadi itu semakin dapat menghayati kebebasannya sehingga ia dapat semakin bertanggung jawab atas pertumbuhan dirinya sendiri sebagai pribadi dan perkembangan orang lain dalam hidup mereka. Secara singkat pendidikan karakter bisa diartikan sebagai sebuah bantuan sosial agar individu itu dapat bertumbuh dalam menghayati kebebasannya dalam hidup bersama dengan orang lain dalam dunia. Ada beberapa nilai-nilai karakter Menurut Aqib (2011:7), diantaranya :

a) Nilai karakter dalam hubungannya dengan Tuhan

b) Nilai karakter dalam hubungannya dengan diri sendiri

c) Nilai karakter dalam hubungannya dengan sesama

d) Nilai karakter dalam hubungannya dengan lingkungan

e) Nilai kebangsaan

Menurut Asmani (2012:36) berdasarkan dari berbagai nilai agama, norma sosial, peraturan atau hukum, dan prinsip-prinsip HAM, telah teridentifikasi butir-butir nilai yang dikelompokkan menjadi lima nilai utama, yaitu nilai-nilai karakter manusia dalam hubungannya dengan Tuhan Yang Maha Esa, diri sendiri, sesama manusia, lingkungan, dan kebangsaan.

\section{Konsep Perilaku}

Menurut Desmita (2011:238) tingkah laku adalah berasal dari diri seseorang yang disebut sebagai sumber endosentris. Sumber endosentris adalah keinginan untuk 
mengubah diri, yaitu memajukan self-image. Keinginan mengubah diri tersebut sebagai suatu cara meningkatkan self-image positif yang berfokus kepada aspek self-moral. Menurut Notoadmodjo (Sugihartono, 2007:56) perilaku adalah suatu kegiatan atau aktivitas organisme yang bersangkutan, yang dapat diamati secara langsung maupun tidak langsung. Perilaku manusia adalah suatu aktivitas manusia itu sendiri .

Menurut Zuriah (2011: 38) Perilaku manusia adalah nilai-nilai hidup manusia yang sungguh-sungguh dilaksanakan bukan sekedar kebiasaan, tetapi berdasar pemahaman dan kesadaran diri untuk menjadi baik. Perilaku menurut Walgito (2005:168) adalah suatu aktivitas yang mengalami perubahan dalam diri individu. Perubahan itu didapat dalam segi kognitif, afektif, dan psikomotorik. Menurut Saifuddin (2010:21) perilaku merupakan fungsi karakteristik individu dan lingkungan. Menurut Nashir (2013: 71) terdapat beberapa nilai perilaku, diantaranya :

1) Jujur

2) Berani

3) Adil

4) Disiplin

5) Tanggung Jawab

6) Sopan Santun

7) Kasih Sayang

\section{PROSEDUR PENELITIAN}

\section{Metode Penelitian}

Penelitian ini menggunakan tipe penelitian kuantitatif dengan jenis penelitian survei, karena penelitian ini dilakukan dengan cara mengambil sampel dari populasi dan menggunakan angket untuk mendapatkan informasi dari responden. Dengan tujuan memberikan gambaran akan penelitian yang memberikan opini ataupun jawaban dari sampel yang ditentukan agar mengetahui pengaruh antara dua variabel atau lebih untuk menentukan ada atau tidaknya pengaruh antar dua variabel tersebut,

\section{Populasi dan Sampel}

Populasi penelitian seluruh siswa Madrasah Ibtidaiyah Sindangjawa yang berjumlah 112 orang. Teknik pengambilan sampel menggunakan rumus slovin

$n=\frac{N}{1+N e^{2}}$

$n=\frac{112}{1+112(0,05)^{2}}$

$n=87,5=88$

\section{Teknik Pengumpulan Data}

Teknik pengumpulan data yang peneliti gunakan dalam penelitian ini adalah: angket,observasi, dokumentasi Uji Validitas Pendidikan Karakter dari 30 item instrumen pendidikan karakter, terdapat 4 item pernyataan yang tidak valid dan sisanya 26 item yang valid. Dari 26 pernyataan yang valid akan diujikan kepada responden. Uji Validitas Perilaku Siswa dari 30 item pernyataan instrumen perilaku siswa terdapat 1 item yang tidak valid dan 29 item valid. 1 item butir pernyataan yang tidak valid diganti dengan 
pernyataan yang maksud dan tujuan yang sama. Jadi yang di ujikan 29 item yang valid dan 1 item pernyataan yang di ganti dengan maksud dan tujuan yang sama, jadi seluruh pernyataan sebanyak 30 item. Uji Reliabilitas Pendidikan karakter sebesar 0,775 dan reliabilitas perilaku siswa sebesar 0,862 . Besarnya nilai lebih dari alpha yaitu $(\alpha=0,60)$, maka kedua variabel tersebut reliabel.

\section{Teknik Analisis Data}

Teknik analisis data yang digunakan dalam penelitian ini adalah teknik analisis regresi linier sederhana. Namun sebelum dilakukan analisis, dilakukan uji prasyarat yang meliputi uji normalitas, uji homogenitas dan uji autokorelasi. Uji normalitas data merupakan salah satu uji mendasar yang dilakukan sebelum melakukan analisis data lebih dalam. Dasar pengambilan keputusan dalam uji normalitas adalah jika nilai signifikansi $>0,05$ maka data tersebut berdistribusi normal. Sebaliknya, jika nilai signifikansi $<0,05$ maka data tersebut tidak berdistribusi normal.

Uji homogenitas dilakukan untuk mengetahui apakah varians sampel yang diambil homogen atau tidak. Jika nilai signifikansi $<0,05$, maka dikatakan bahwa varian dari dua atau lebih kelompok populasi data adalah tidak sama. Jika nilai signifikansi $>0,05$, maka dikatakan bahwa varian dari dua atau lebih kelompok populasi data adalah sama. Uji autokorelasi dilakukan untuk mengetahui apakah dalam sebuah model regresi linier terdapat hubungan yang kuat baik positif maupun negatif antara data yang ada pada variabel-variabel penelitian. Untuk data cross section, akan diuji apakah terdapat hubungan yang kuat antara data pertama dengan data kedua, data kedua dengan ketiga dan seterusnya

Analisis regresi digunakan untuk mengetahui bagaimana variabel dependent (terikat) dapat diprediksikan (meramalkan) melalui variabel independent (bebas) secara parsial ataupun secara bersama-samam (stimulan). Analisis regresi dapat digunakan untuk menaikan atau menurunkan variabel independent. Pengambilan keputusan dalam uji regresi sederhana dapat mengacu pada dua hal, yakni dengan membandingkan nilai $t$ hitung dengan $\mathrm{t}$ tabel, atau dengan membandingkan nilai signifikansi dengan nilai probabilitas.

\section{HASIL DAN PEMBAHASAN}

Kecenderungan tentang tinggi rendahnya nilai skor dalam pendidikan karakter dan perilaku siswa berdasarkan pada kriteria skor ideal. Berikut ini kategori disajikan dalam diagram lingkaran pendidikan karakter : 


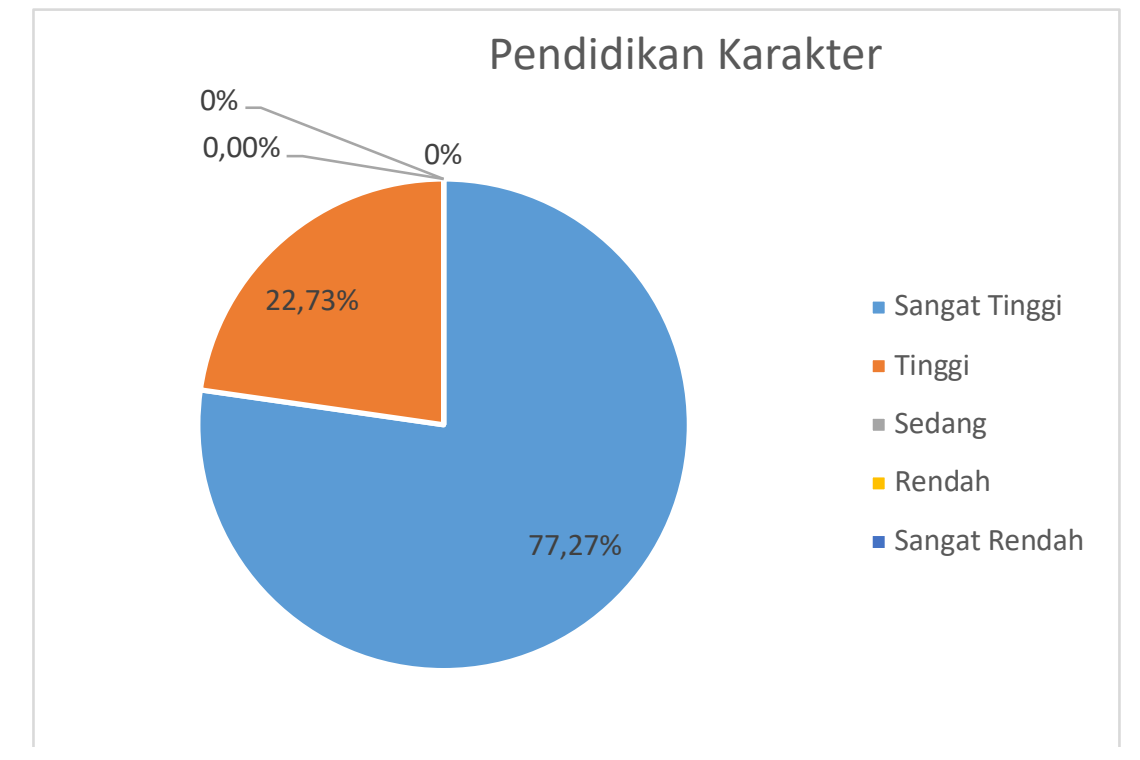

Gambar 1. Pendidikan Karakter Siswa

Berdasarkan gambar diagram lingkaran di atas kriteria siswa diperoleh skor sebesar $88,64 \%$ pada kategori sangat tinggi yang diwakili oleh 78 responden, maka pendidikan karakter siswa dikategorikan sangat tinggi. Sedangkan untuk hasil perilaku siswa dapat dilihat dalam gambar di bawah ini

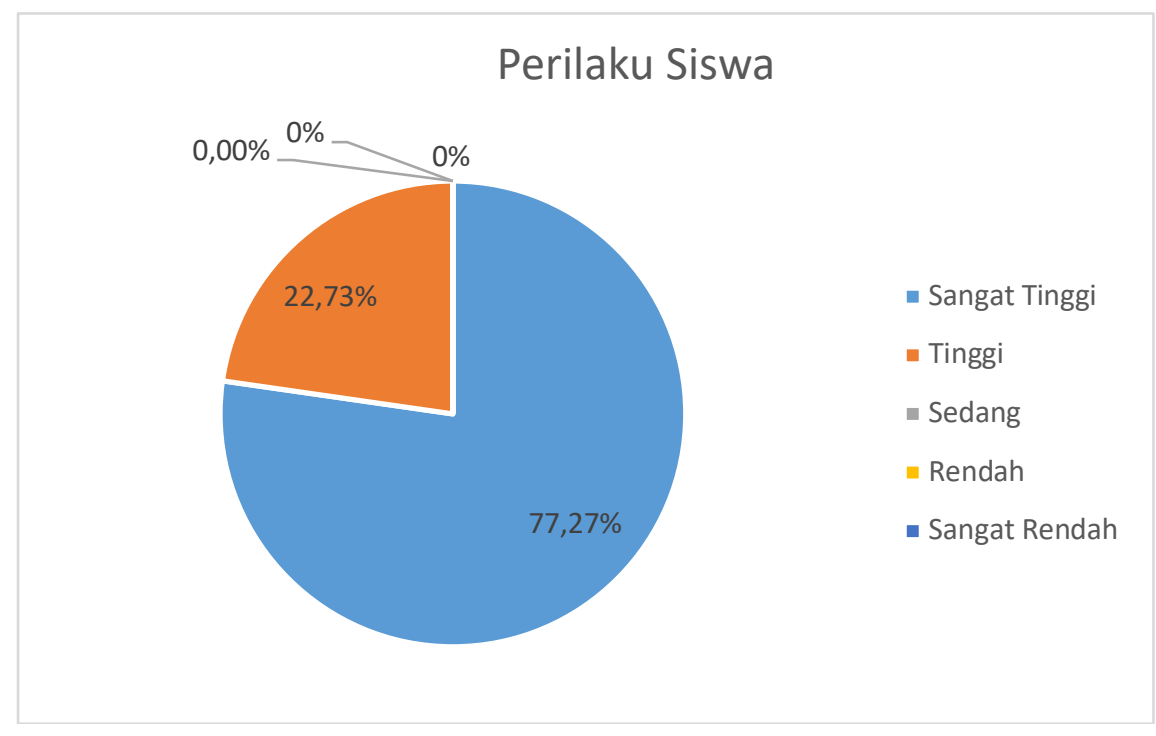

Gambar 2. Perilaku Siswa 
Berdasarkan gambar diagram lingkaran di atas kriteria siswa diperoleh skor sebesar $77,27 \%$ pada kategori sangat tinggi yang diwakili oleh 68 responden. Berdasarkan hasil penelitian bahwa pendidikan karakter termasuk kategori sangat tinggi. Hal ini dilihat dari perolehan skor pada kuesioner sebesar $88,64 \%$ yang diwakili oleh 78 responden, $4,55 \%$ pada kategori tinggi yang diwakili oleh 4 responden dan $6,82 \%$ pada kategori sedang diwakili oleh 6 responden. Sedangkan perilaku siswa berdasarkan hasil angket menunjukkan bahwa perilaku siswa Madrasah Ibtidaiyah Sindangjawa berkategori sangat baik dengan skor sebesar $77,27 \%$ yang diwakili oleh 68 responden dan sisanya berkategori baik sebesar 22,73\% yang diwakili oleh 20 responden. Dari hasil penelitian yang telah dikemukakan di atas, maka terdapat pengaruh variabel independent (pendidikan karakter) dan variabel dependent (perilaku siswa) berpengaruh positif. Hal tersebut dapat dibuktikan melalui hasil analisis regresi sederhana, dengan menunjukkan koefisien korelasi (r) sebesar 0,446, dan Rsquare sebesar 0,526. Hal ini berarti bahwa pendidikan karakter mempunyai pengaruh yang positif sebesar 52,6\% terhadap perilaku siswa. Setelah uji f diperoleh fhitung sebesar 4,483. Nilai ftabel pada taraf signifikansi $5 \%$ dan derajat kebebasan $\mathrm{dk}=86$ sebesar 3,95, maka d disimpulkan bahwa fhitung $>$ ftabel, dan tingkat signifikansi $0,000>0,05$. Berdasarkan hasil analisis regresi diperoleh thitung sebesar 4,948, dan ttabel $(\mathrm{d}-\mathrm{k})(88-2=86)$ yaitu sebesar 1,662 Maka thitung $>$ ttabel dan nilai $\mathrm{p}$ value (Sig.) $0,000<0,05$. Sedangkan persamaan regresinya yaitu $\mathrm{Y}=$ $147.325+0,471 X$, Maka dapat disimpulkan bahwa Ho ditolak H1 diterima, yang artinya ada pengaruh positif pendidikan karakter terhadap perilaku siswa.

Berdasarkan hasil diatas dapat dikatakan bahwa semakin tinggi (positif) pendidikan karakter di sekolah maka akan semakin tinggi pula perilaku siswa di sekolah. Hasil penelitian menyatakan "ada pengaruh positif antara pendidikan karakter terhadap perilaku siswa". Pendidikan karakter ini memberikan sumbangan efektif sebesar $21,40 \% \%$ terhadap perilaku siswa, dan memberikan sumbangan relatif sebesar $57,29 \%$ terhadap perilaku siswa. Nilai correlation sebesar 0,273 , maka terdapat hubungan yang signifikan antara pendidikan karakter terhadap perilaku siswa dengan nilai signifikan sebesar 0,000 dan tingkat hubungan antara pendidikan karakter dan perilaku siswa hubungannya rendah.

\section{KESIMPULAN DAN SARAN}

\section{Kesimpulan}

Berdasarkan penelitian yang dilakukan hasil analisis data yang diperoleh maka yang menjadi kesimpulan umum yaitu :

1. Pendidikan karakter siswa tergolong sangat tinggi, hal ini terlihat dari data yang terkumpul menunjukkan bahwa pendidikan karakter termasuk kategori sangat tinggi yang di wakili oleh 78 responden dengan persentasi 88,64\%.

2. Perilaku siswa menunjukan kategori sangat baik, hal ini terlihat dari data yang terkumpul menunjukkan bahwa persentase perilaku siswa berkategori sangat baik sebesar 77,27\% yang diwakili oleh 68 responden.

3. Variabel bebas berpengaruh secara signifikan terhadap variabel terikat. Dengan diperoleh Fhitung $=4,483$ dengan dn $1(\mathrm{k}-1)=(2-1)=1$ sedangkan $\mathrm{dn} 2=(\mathrm{n}-\mathrm{k})=(88$ $2)=86$, pengujian dilakukan pada sig 5\%, maka nilai ftabel $=3,95$, dapat diartikan bahwa Ho ditolak karena fhitung $>$ ftabel. Sedangkan tingkat sig 0,000 $>0,05$ maka artinya variabel bebas berpengaruh secara siginifikan terhadap variabel terikat. 
Berdasarkan hasil yang didapat mengungkapkan bahwa terdapat pengaruh positif antara pendidikan karakter terhadap perilaku siswa karena thitung $>$ ttabel dan nilai p value (Sig.) $0,000<0,05$, dan rsquare sebesar 0,526 sehingga pengaruh antara pendidikan karakter terhadap perilaku siswa sebesar 52,6\%. Maka terdapat hubungan yang positif antara pendidikan karakter terhadap perilaku siswa dimana apabila pendidikan karakter meningkat 1\% maka akan diikuti pula peningkatan perilaku siswa sebesar 0,471 dimana semakin tinggi pendidikan karakter semakin baik pula perilaku siswa.

\section{SARAN} berikut:

Dari hasil penelitian kesimpulan di atas, maka penulis mengajukan saran sebagai

1. Bagi guru, diharapkan dapat memberikan pelajaran pendidikan karakter yang baik dan memperhatikan penuh terhadap perilaku siswa, agar siswa menjadi anak yang lebih berperilaku baik.

2. Bagi lembaga yang terkait dalam memberikan bantuan, bimbingan, dan pembinaan perlu memperhatikan pendidikan karakter yang ditanamkan oleh guru, agar perilaku siswa lebih baik lagi.

3. Bagi Siswa, seyogyanya lebih meningkatkan perilakunya dengan cara menumbuhkan karakter yang baik yang telah ditanamkan oleh guru dan pihak lembaga.

4. Bagi peneliti selanjutnya untuk meningkatkan kualitas penelitian lebih lanjut khususnya yang berkaitan dengan perilaku siswa. Peneliti lain dapat menyempurnakan hasil penelitian ini dengan menambah atau mengganti dengan variabel lain yang belum diungkapkan dalam penelitan ini. Sehingga penelitian dapat lebih berkembang.

\section{DAFTAR PUSTAKA}

Ahmad \& Uhbiyati. (2007). Ilmu Pendidikan. Jakarta : Rineka Cipta.

Asmani, Ma'mur Jamal. (2009). Tips Menjadi Guru Inspiratif, Kreatif Dan Inovatif. Jogjakarta: Diva Press.

Asmani, Ma'mur Jamal. (2012). Buku Panduan Internalisasi Pendidikan Karakter di Sekolah. Yogyakarta : Diva Press.

Aqib, Zainal. (2011). Pendidikan Karakter membangun Perilaku Positif anak Bangsa. Bandung: CV. Yrama Widya.

Azwar, Saifuddin. (2007). Penyusunan Skala Psikologi. Yogyakarta: Pustaka Pelajar.

Danim, Sudarwan. (2011). Pengantar Pendidikan. Bandung: Alfabeta.

Desmita. (2011). Psikologi Perkembangan peserta didik. Bandung: PT Remaja Rosdakarya.

Hidayatullah, Furqon. (2010). Pendidikan Karakter Membangun Peradaban Bangsa. Surakarta: Yuma Pustaka.

Koesoema, Doni. (2007). Pendidikan Karakter. Jakarta:Grasindo. 
Majid, Abdul. (2012). Pendidikan Karakter perspektif Islam. Bandung: PT Remaja Rosdakarya.

Nashir, Header. (2013). Pendidikan Karakter berbasis Agama dan Kebudayaan. Yogyakarta: Multi Presindo.

Oemar, Hamalik. (2003). Proses Belajar Mengajar. Jakarta: Bumi Aksara.

Soedarsono, Soemarno. (2009). Karakter pengantar Bangsa dan Kegelapan menjadi Terang. Jakarta: PT Elex Media Komputindo.

Sugihartono. (2007). Psikologi Pendidikan. Yogyakarta: UNY Press.

Sujak\&Aqib, Zainal, (2011). Panduan dan Aplikasi Pendidikan Karakter. Bandung: Yrama Widya.

Suwedo, Erie. (2011). Character Building: Menuju Indonesia Lebih Baik. Jakarta: Republik Grafindo Persada.

Zuriah, Nurul. (2011). Pendidikan Moral dan Budi Pekerti dalam Prepektif Perubahan. Jakarta: PT Bumi Aksara 